\title{
Hydration states in interlayer of hydromuscovite
}

\author{
Motoharu Kawano and Katsutoshi Tomita \\ Institute of Earth Sciences, Faculty of Science, Kagoshima University \\ 1-21-35 Korimoto, Kagoshima 890, Japan
}

\begin{abstract}
Hydration states of hydromuscovites under conditions of $80 \%$ and $50 \%$ R.H. and glycerol solvation after saturation with various kinds of cations in the expandable interlayers were examined by means of Fourier transform analysis.

At $80 \%$ R.H., Ca-saturated specimens showed one- and two-layer hydration states of expan. dable layer and the ratios of two-layer to one-layer hydration states decrease with increasing the proportions of mica layer components. At $50 \%$ R.H., Ca-saturated specimens indicated a decrease in two-layer hydration and an increase in one-layer hydration as compared with those of the specimens at $80 \%$ R.H. Glycerol solvated complexes of Mg-saturated specimens showed that the specimens contain one-layer glycerol complexes with spacing of about $12.5 \AA$.

These hydration states of the hydromuscovites are different from those of smectites and expandable layers of regularly interstratified mica/smectites, and it is considered to be due to their high layer charge in expandable layer.
\end{abstract}

\section{Introduction}

The AIPEA Nomenclature Committee has shown the classification scheme for the phyllosilicates related to clay minerals based on its layer type (ratio of tetrahedral to octahedral sheets in one repetitive unit structure) and charge density. Although, the Committee recommended that the definition of mica is $2: 1$ layer type clay minerals with layer charge of 1 per formula unit, it has written that "the status of illite (or hydromica), sericite, etc. must be left open at present, because it is not clear whether or at what level they would enter the Table (Bailey, 1980); many materials so designated may be interstratified". At present, many studies have been conducted to clarify the mineralogical properties of these minerals (Grim et al., 1937; Kodama, 1957; Kodama, 1962; Hower and Mowatt, 1966; Shimoda, 1970 , etc.). As to the chemical composition, these micas show excess of water and deficiency of potassium in interlayer positions and aluminum in tetrahedral sheets as compared with theoretical composition of muscovites, suggesting that the layer charge of the former is slightly lower than that of latter (Hower and Mowatt, 1966). As to the structure of interstratification, these micas include two types of minerals, one is interstratified mica/ smectite with small amounts of expandable layers, the other is pure mica with no interstratification structure (Shirozu and Higashi, 1972).

The present study deals with the hydration states in the interlayers of hydromuscovites (interstratified mica/smectites with small amounts of expandable layers) and their nature of interstratifications.

\section{Specimens}

Five hydromuscovites with small amounts of expandable layers were examined in this study. They are as follows;

H1: Specimen from Tenei, Fukushima Prefecture (Kawano, 1988). 
H2: Specimen from Makurazaki, Kagoshima Prefecture.

H3: Specimen from Tenei, Fukushima Prefecture (Kawano, 1988).

H4: Specimen from Silver Hill, Montana, U.S.A. (Hower and Mowatt, 1966) supplied from the Source Clays Repository of The Clay Minerals
Society.

H5 : Specimen from Aira, Kagoshima Prefecture (Kawano and Tomita, 1988).

The chemical analysis of specimen $\mathrm{H} 2$ was carried out by usual wet method. The chemical analyses and structural formulae for these specimens are listed in Table 1.

Table 1. Chemical analyses and structural formulae for hydromuscovites

\begin{tabular}{|c|c|c|c|c|c|}
\hline & $\mathrm{H} 1$ & $\mathrm{H} 2$ & $\mathrm{H3}$ & H4 & $\mathrm{H} 5$ \\
\hline $\mathrm{SiO}_{2}$ & 49.04 & 46.69 & 48.06 & 55.10 & 48.98 \\
\hline $\mathrm{TiO}_{2}$ & 0.13 & 0.05 & 0.09 & 0.63 & 0.02 \\
\hline $\mathrm{Al}_{2} \mathrm{O}_{3}$ & $28 \cdot 30$ & 34.12 & 31,31 & 22.00 & 33.82 \\
\hline $\mathrm{Fe}_{2} \mathrm{O}_{3}$ & 4.43 & 0.48 & 0.51 & 5.28 & 0.58 \\
\hline $\mathrm{F} \in \mathrm{O}$ & - & - & - & 1.34 & - \\
\hline MnO & 0.04 & 0.01 & 0.51 & - & 0.01 \\
\hline Mgo & 0.81 & 0.59 & 1.04 & 2.80 & 0.61 \\
\hline $\mathrm{CaO}$ & 0.58 & 0.07 & 0.64 & 0.02 & 0.02 \\
\hline $\mathrm{Na}_{2} \mathrm{O}$ & 0.34 & 1.18 & 1.18 & 0.08 & 1.33 \\
\hline $\mathrm{K}_{2} \mathrm{O}$ & 7.14 & 6.25 & 6.61 & 8.04 & 5.99 \\
\hline$\left(\mathrm{NH}_{4}\right)_{2} \mathrm{O}$ & - & - & - & - & 1.30 \\
\hline $\mathrm{P}_{2} \mathrm{O}_{5}$ & 0.26 & - & 0.21 & - & - \\
\hline $\mathrm{H}_{2} \mathrm{O}(+)$ & 5.54 & 7.95 & 6.48 & 6.40 & 5.25 \\
\hline $\mathrm{H}_{2} \mathrm{O}(-)$ & 4.08 & 2.70 & 3.87 & 1.00 & 1.86 \\
\hline Total $(8)$ & 100.69 & 100.09 & 99.96 & 102.69 & 99.82 \\
\hline \multicolumn{6}{|l|}{ Tetrahedral } \\
\hline $\mathrm{Si}$ & 3.37 & 3.20 & 3.31 & 3.66 & 3.25 \\
\hline \multicolumn{6}{|l|}{ octahedral } \\
\hline $\mathrm{Al}$ & 1.66 & 1.96 & 1.85 & 1.38 & 1.89 \\
\hline $\mathrm{Fe}^{3+}$ & 0.23 & 0.02 & 0.03 & 0.26 & 0.03 \\
\hline $\mathrm{Fe}^{2+}$ & - & - & - & 0.07 & - \\
\hline $\mathrm{Mg}$ & 0.07 & 0.02 & 0.09 & 0.28 & 0.06 \\
\hline Ti & 0.01 & 0.00 & 0.00 & - & 0.00 \\
\hline Sum & 1.97 & 2.01 & 1.97 & 1.99 & 1.98 \\
\hline Interlayer & & & & & . \\
\hline $\mathrm{Ca}$ & 0.0 .4 & 0.01 & 0.05 & - & 0.00 \\
\hline $\mathrm{Na}$ & 0.05 & 0.16 & 0.16 & 0.01 & 0.18 \\
\hline $\mathrm{k}$ & 0.63 & 0,55 & 0.58 & 0.68 & 0.51 \\
\hline $\mathrm{NH}_{4}$ & - & - & - & - & 0.20 \\
\hline $\mathrm{Mg}$ & 0.01 & 0.04 & 0.02 & - & - \\
\hline$x^{+}$ & - & - & - & 0.03 & - \\
\hline Sum & 0.72 & 0.76 & 0.81 & 0.72 & 0.89 \\
\hline Total charge & 0.78 & 0.79 & 0.87 & 0.72 & 0.89 \\
\hline
\end{tabular}




\section{Experimental method}

Fractions less than $2 \mu \mathrm{m}$ were obtained by usual sedimentation method, and were saturated with $\mathrm{Ca}^{2+}, \mathrm{Na}^{+}$and $\mathrm{Mg}^{2+}$ by treatment with $1 \mathrm{~N} \mathrm{CaCl}, \mathrm{NaCl}$ and $\mathrm{MgCl}_{2}$ solution. After the removal of excess salt by washing with $80 \%$ ethanol, the homoionic specimens were oriented on glass slides.

$\mathrm{X}$-ray diffraction analysis was carried out by Rigaku diffractometer using $\mathrm{CuK}_{\alpha}$ radiation under the conditions of $80 \%$ and $50 \%$ relative humidities for $\mathrm{Ca}$-saturated specimens, $50 \%$ relative humidity for $\mathrm{Na}$-saturated specimens, and glycerol solvated complexes of $\mathrm{Mg}$-saturated specimens. The basal spacings were obtained from $d$-values of the center half the height of basal reflections and intensities were determined by step scan method. The control of humidity was made by ordinary humidifier and dehumidifier equipment. These instruments were run in the $\mathrm{x}$-ray room and humidities were checked by hygrometer.

The hydration states in expandable layers and nature of the interstratifications were examined by means of Fourier transform analyses, and the equation employed in this calculation was formulated by MacEwan (1956) and can be written as

$$
W(R)=\sum_{l} \frac{I}{E\left|F_{l}\right|^{2}} \cos 2 \pi \mu_{l} R,
$$

where function $W(R)$ is defined as the probabil. ity of finding another layer at a distance $R$ from any layer. $I$, the integrated intensity, $E$, the geometric factor, $\left|F_{l}\right|^{2}$, the square of the layer structure factor and $\mu_{l}$, the reciprocal spacing. $\left(1+\cos ^{2} 2 \theta / \sin 2 \theta\right)$ was used for the factor $E$. The layer structure factors were taken from Cole and Lancucki (1966) for hydrous dioctahedral mica type layers.

\section{Results}

Hydration states of $\mathrm{Ca}$-saturated specimens at 80\% R.H.

Basal spacings and intensities of Ca-saturated specimens obtained under the condition of $80 \%$ R.H. are listed in Table 2. Fig. 1 shows Fourier transforms of basal reflections for the five specimens. These transforms show three fundamental components ( $\mathrm{A}, \mathrm{B}$ and $\mathrm{C}$ ) with spacings of about 10,13 and $15.4 \AA$, which are assigned to mica layer, expandable layer of one-layer hydration and that of two-layer hydration, respectively. Table 3 shows calculated and observed heights of peaks from Fourier transforms of basal reflections for Ca-saturated hydromuscovites at $80 \%$ R.H. The calculated heights of peaks were determined by

Table 2. Spacings ( $\AA$ ) and intensities of basal reflections for Ca-saturated hydromuscovites at $80 \%$ R.H.

\begin{tabular}{|c|c|c|c|c|c|c|c|c|c|}
\hline \multicolumn{2}{|c|}{$\mathrm{H} 1$} & \multicolumn{2}{|c|}{$\mathrm{H} 2$} & \multicolumn{2}{|c|}{$\mathrm{H} 3$} & \multicolumn{2}{|c|}{$\mathrm{H} 4$} & \multicolumn{2}{|c|}{ H5 } \\
\hline$d(\stackrel{D}{A})$ & I. & $d(A ̊)$ & I & $d(\stackrel{A}{A})$ & I & $d(\stackrel{A}{A})$ & I & $\mathrm{d}(\stackrel{2}{)})$ & I \\
\hline 11.5 & 1000 & 10.7 & 1000 & 10.4 & 1000 & 10.3 & 1000 & 10.2 & 1000 \\
\hline 5.04 & 265 & 5.05 & 323 & 5.02 & 314 & 5.03 & 166 & 5.02 & 242 \\
\hline 3.290 & $531^{\circ}$ & 3.319 & 427 & 3.309 & 448 & 3.325 & 433 & 3.339 & 325 \\
\hline 2.521 & 36 & 2.521 & 26 & 2.512 & 19 & 2.509 & 21 & 2.514 & 16 \\
\hline 1.993 & 151 & 1.998 & 130 & 1.995 & 133 & 1.996 & 114 & 2.006 & 91 \\
\hline 1.654 & 1 & 1.655 & 2 & 1.654 & 1 & 1.667 & 3 & 1.658 & 1 \\
\hline 1.424 & 7 & 1.427 & 7 & 1.426 & 5 & 1.425 & 9 & 1.430 & 3 \\
\hline 1.251 & 10 & 1.252 & 7 & 1.251 & 5 & 1.247 & 8 & 1.251 & 4 \\
\hline
\end{tabular}




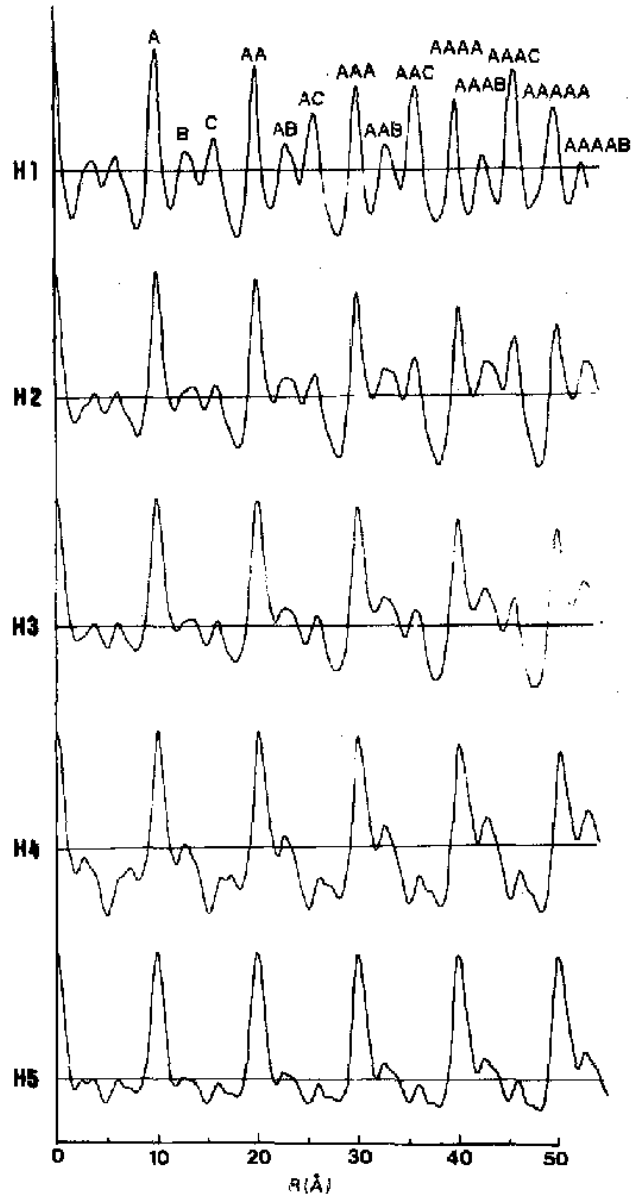

Fig. 1. Fourier transform of basal reflections for $\mathrm{Ca}$-saturated hydromuscovites at $80 \%$ R.H.

the method of MacEwan (1956), and observed heights of peaks were obtained from heights of peaks in Fourier transform. The values for calculated and observed heights of peaks A, B and $\mathrm{C}$ represent proportions of component layers. The results suggest that specimens $\mathrm{H} 1$, $\mathrm{H} 2$ and $\mathrm{H} 3$ are composed of three component layers, which are mica layer, expandable layer of one-layer hydration and that of two-layer hydration, while specimens $\mathrm{H} 4$ and $\mathrm{H} 5$ are composed of two component layers, which are mica layer and expandable layer of one-layer hydration. The existing ratios of one-layer to two-layer hydration increase with increasing

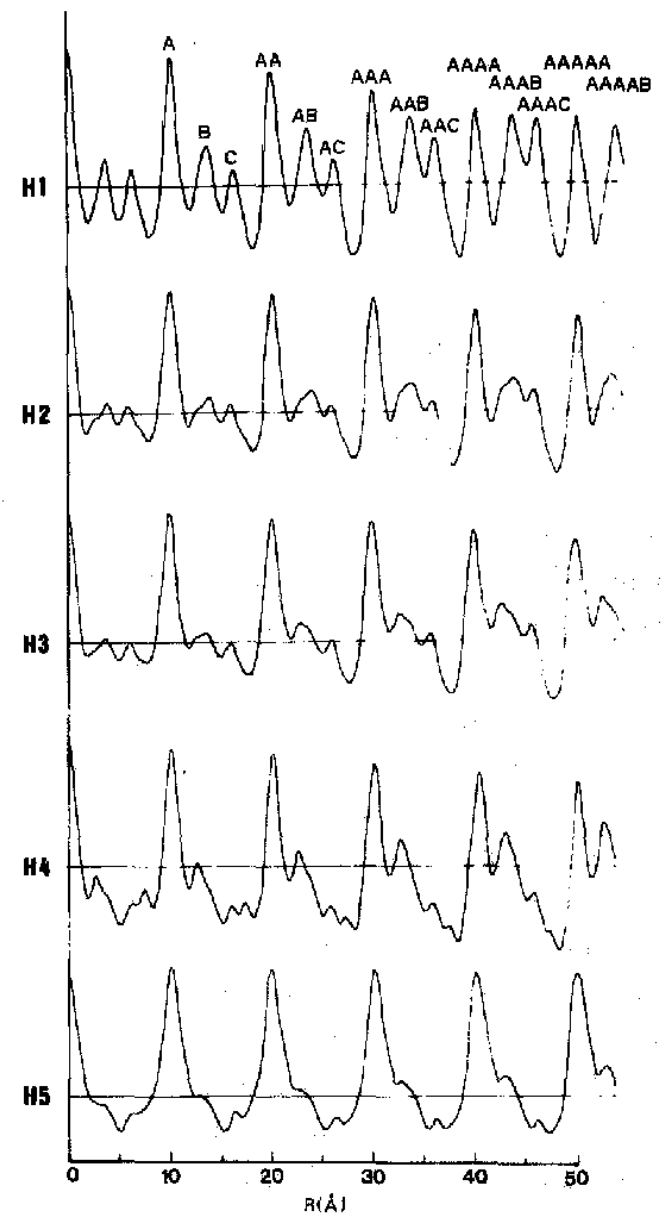

Fig. 2, Fourier transform of basal reflections for Ca-saturated hydromuscovites at 50\% R.H.

the proportions of mica layer components.

Hydration states of $\mathrm{Ca}$-saturated specimens at $50 \%$ R.H.

Table 4 shows the basal spacings and intensities of Ca-saturated specimens at $50 \%$ R.H. Under the humidity condition, the first order reflection shifts slightly to higher angle while the third and fifth order reflections shift to lower angle compared with those of the specimens under the condition of $80 \%$ R.H. Fig. 2 shows Fourier transforms for Ca-saturated specimens at $50 \%$ R.H. These transforms indicate that expandable layers of two-layer hydration decrease and those of one-layer hydration 
Table 3. Calculated and observed heights of peaks from Fourier transform of basal reflections for Ca-saturated hydromuscovites at $80 \%$ R.H.

\begin{tabular}{|c|c|c|c|c|c|c|c|c|c|}
\hline Peak & $\begin{array}{c}\text { Spacing } \\
(\mathbb{A})\end{array}$ & $\begin{array}{c}\mathbf{H 1} \\
\text { Caleulated } \\
\text { height }\end{array}$ & $\begin{array}{c}\text { Observed } \\
\text { height }\end{array}$ & $\begin{array}{c}\text { Spacing } \\
(A)\end{array}$ & $\begin{array}{c}\mathrm{H2} \\
\text { Caloulated } \\
\text { height }\end{array}$ & $\begin{array}{l}\text { Observed } \\
\text { height }\end{array}$ & $\begin{array}{c}\text { Spaging } \\
(\text { (f) }\end{array}$ & $\begin{array}{c}\text { H3 } \\
\text { Caleulated } \\
\text { height }\end{array}$ & $\begin{array}{c}\text { Observed } \\
\text { height }\end{array}$ \\
\hline $\begin{array}{l}\text { A } \\
\text { B } \\
\text { C } \\
\text { AA } \\
\text { AB } \\
\text { AC } \\
\text { AAA } \\
\text { AAB } \\
\text { AAC } \\
\text { AAAA } \\
\text { AAAB } \\
\text { AAAC } \\
\text { AAAAA } \\
\text { AAAAB }\end{array}$ & $\begin{array}{l}10.0 \\
12.8 \\
15.9 \\
20.0 \\
22.8 \\
25.8 \\
29.9 \\
32.7 \\
35.8 \\
39.9 \\
42.7 \\
45.8 \\
49.9 \\
52.6\end{array}$ & $\begin{array}{l}0.68 \\
0.12 . \\
0.20 \\
0.59 \\
0.17 \\
0.24 \\
0.50 \\
0.20 \\
0.25 \\
0.43 \\
0.22 \\
0.25 \\
0.37 \\
0.23\end{array}$ & $\begin{array}{l}0.68 \\
0.12 \\
0.20 \\
0.59 \\
0.17 \\
0.34 \\
0.48 \\
0.16 \\
0.48 \\
0.40 \\
0.10 \\
0.56 \\
0.36 \\
0.04\end{array}$ & $\begin{array}{l}10.0 \\
13.8 \\
15.9 \\
20.1 \\
22.3 \\
25.9 \\
30.1 \\
32.8 \\
35.9 \\
40.1 \\
42.9 \\
45.8 \\
50.1 \\
52.9\end{array}$ & $\begin{array}{l}0.85 \\
0.07 \\
0.08 \\
0.79 \\
0.13 \\
0.08 \\
0.74 \\
0.17 \\
0.08 \\
0.68 \\
0.21 \\
0.08 \\
0.64 \\
0.25\end{array}$ & $\begin{array}{l}0.85 \\
0.07 \\
0.08 \\
0.79 \\
0.13 \\
0.16 \\
0.71 \\
0.19 \\
0.26 \\
0.60 \\
0.22 \\
0.38 \\
0.49 \\
0.22\end{array}$ & $\begin{array}{l}10.0 \\
13.7 \\
16.0 \\
20.0 \\
22.7 \\
25.9 \\
30.0 \\
32.7 \\
35.8 \\
40.0 \\
42.7 \\
45.7 \\
50.0 \\
52.7\end{array}$ & $\begin{array}{l}0.93 \\
0.04 \\
0.03 \\
0.90 \\
0.10 \\
0.00 \\
0.86 \\
0.14 \\
0.00 \\
0.83 \\
0.17 \\
0.00 \\
0.80 \\
0.20\end{array}$ & $\begin{array}{l}0.93 \\
0.04 \\
0.03 \\
0.90 \\
0.10 \\
0.06 \\
0.84 \\
0.19 \\
0.12 \\
0.77 \\
0.25 \\
0.19 \\
0.58 \\
0.30\end{array}$ \\
\hline Peak & $\begin{array}{c}\text { Spacing } \\
(A))\end{array}$ & $\begin{array}{l}\text { Hu } \\
\text { Calculatad } \\
\text { height }\end{array}$ & $\begin{array}{l}\text { Observed } \\
\text { height }\end{array}$ & $\begin{array}{c}\text { Spacing } \\
(A)\end{array}$ & $\begin{array}{c}45 \\
\text { Calculated } \\
\text { height }\end{array}$ & $\begin{array}{l}\text { Observed } \\
\text { height. }\end{array}$ & & & \\
\hline $\begin{array}{l}\text { A } \\
\text { B } \\
\text { AA } \\
\text { AB } \\
\text { ABA } \\
\text { AAB } \\
\text { AAAA } \\
\text { AAAB } \\
\text { AAAAA } \\
\text { AAAAB }\end{array}$ & $\begin{array}{l}10.0 \\
12.6 \\
20.0 \\
22.6 \\
30.0 \\
32.5 \\
40.0 \\
42.7 \\
50.0 \\
52.7\end{array}$ & $\begin{array}{l}0.97 \\
0.03 \\
0.95 \\
0.05 \\
0.93 \\
0.07 \\
0.90 \\
0.10 \\
0.08 \\
0.12\end{array}$ & $\begin{array}{l}0.97 \\
0.03 \\
0.95 \\
0.11 \\
0.91 \\
0.18 \\
0.85 \\
0.25 \\
0.79 \\
0.31\end{array}$ & $\begin{array}{l}10.0 \\
12.4 \\
20.1 \\
22.5 \\
30.1 \\
32.5 \\
40.2 \\
42.6 \\
50.2 \\
52.6\end{array}$ & $\begin{array}{l}0.99 \\
0.01 \\
0.99 \\
0.01 \\
0.98 \\
0.02 \\
0.98 \\
0.02 \\
0.97 \\
0.03\end{array}$ & $\begin{array}{l}0.99 \\
0.01 \\
0.99 \\
0.05 \\
0.98 \\
0.10 \\
0.96 \\
0.14 \\
0.94 \\
0.19\end{array}$ & & & \\
\hline
\end{tabular}

Table 4. Spacings $(\AA)$ and intensities of basal reflections for $\mathrm{Ca}-$ saturated hydro. muscovites at $50 \%$ R.H.

\begin{tabular}{|c|c|c|c|c|c|c|c|c|c|}
\hline \multicolumn{2}{|c|}{$\mathrm{H} 1$} & \multicolumn{2}{|c|}{$\mathrm{H} 2$} & \multicolumn{2}{|c|}{ H3 } & \multicolumn{2}{|c|}{$\mathrm{H} 4$} & \multicolumn{2}{|c|}{ H5 } \\
\hline$d\left(\AA^{\circ}\right)$ & $I$ & $\mathrm{~d}(\AA)$ & I & $d(\AA)$ & \pm & $\mathrm{d}(\stackrel{\mathrm{a}}{\mathrm{A}})$ & I & $d(\AA)$ & I \\
\hline 11.1 & 1000 & 10.5 & 1000 & 10.4 & 1000 & 10.3 & 1000 & 10.2 & 1000 \\
\hline 5.03 & 222 & 5.01 & 365 & 5.01 & 302 & 5.01 & 159 & 5.01 & 236 \\
\hline 3.344 & 418 & 3.329 & 505 & 3.314 & 413 & 3.322 & 371 & 3.337 & 320 \\
\hline 2.546 & 3 & 2.507 & 25 & 2.507 & 17 & 2.505 & 26 & 2.512 & 14 \\
\hline 2.004 & 110 & 2.005 & 169 & 1.999 & 122 & 1.996 & 108 & 2.005 & 94 \\
\hline 1.658 & 2 & 1.654 & 1 & 1.650 & 1 & 1.663 & 3 & 1.662 & 1 \\
\hline 1.422 & 5 & 1.431 & 7 & 1.427 & 4 & 1.429 & 8 & 1.430 & 3 \\
\hline 1.251 & 8 & 1.251 & 7 & 1.250 & 5 & 1.249 & 8 & 1.251 & 5 \\
\hline
\end{tabular}

increase as compared with those of the specimens at $80 \%$ R.H.

Hydration states of $\mathrm{Na}$-saturated specimens at $50 \%$ R.H.

Under the condition of $50 \%$ R.H., the first order reflection of $\mathrm{Na}$-saturated specimens shifts to higher angle and the third and fifth order reflections shift to lower angle than those of Ca-saturated specimens (Table 5). These behaviors are caused by shrinkage of expandable layers. The Fourier transforms for $\mathrm{Na}^{-}$ saturated specimens at 50\% R.H. (Fig. 3) show that expandable layers of two-layer hydration decrease and those of one-layer hydration increase as compared with those of Ca-saturated specimens at $50 \%$ R.H.

Glycerol solvated complexes of $\mathrm{Mg}$-saturated specimens

Basal spacings and intensities of glycerol solvated complexes for $\mathrm{Mg}$-saturated specimens are given in Table 6. The first order basal reflection of the specimen $\mathrm{H} 1(11.5 \AA)$ 
Table 5. Spacings ( $\AA$ ) and intensities of basal reflections for Na-saturated hydromuscovites at $50 \%$ R.H.

\begin{tabular}{|c|c|c|c|c|c|c|c|c|c|}
\hline \multicolumn{2}{|c|}{$\mathrm{HT}$} & \multicolumn{2}{|c|}{$\mathrm{H} 2$} & \multicolumn{2}{|c|}{$\mathrm{H}_{3}$} & \multicolumn{2}{|c|}{$\mathrm{H} 4$} & \multicolumn{2}{|c|}{ H5 } \\
\hline$d\left(\frac{0}{2}\right)$ & I & $\mathrm{d}\langle\stackrel{\AA}{\mathrm{a}})$ & I & $\mathrm{d}(\AA)$ & $I$ & $d(\AA)$ & $I$ & $a(\AA ̊ \cap)$ & $I$ \\
\hline 10.6 & 1000 & 10.4 & 1000 & 10.4 & 1000 & 10.3 & 1000 & 10.2 & 1000 \\
\hline 5.08 & 115 & 5.04 & 197 & 5.01 & 308 & 5.03 & 120 & 5.01 & 324 \\
\hline 3.296 & 247 & 3.312 & 289 & 3.322 & 478 & 3.324 & 358 & 3.337 & 473 \\
\hline 2.498 & 9 & 2.507 & 16 & 2.507 & 21 & 2.504 & 16 & 2.509 & 24 \\
\hline 2.008 & 57 & 2.010 & 85 & 2.002 & 153 & 2.001 & 90 & 2.004 & 155 \\
\hline 1.653 & 9 & 1.657 & 1 & 1.658 & 1 & 1.667 & 2 & 1.660 & 1 \\
\hline 1.419 & 3 & 1.425 & 3 & 1.429 & 7 & 1.425 & 7 & 1.430 & 6 \\
\hline 1.248 & 4 & 1.251 & 3 & 1.250 & 7 & 1.246 & 7 & 1.251 & 7 \\
\hline
\end{tabular}
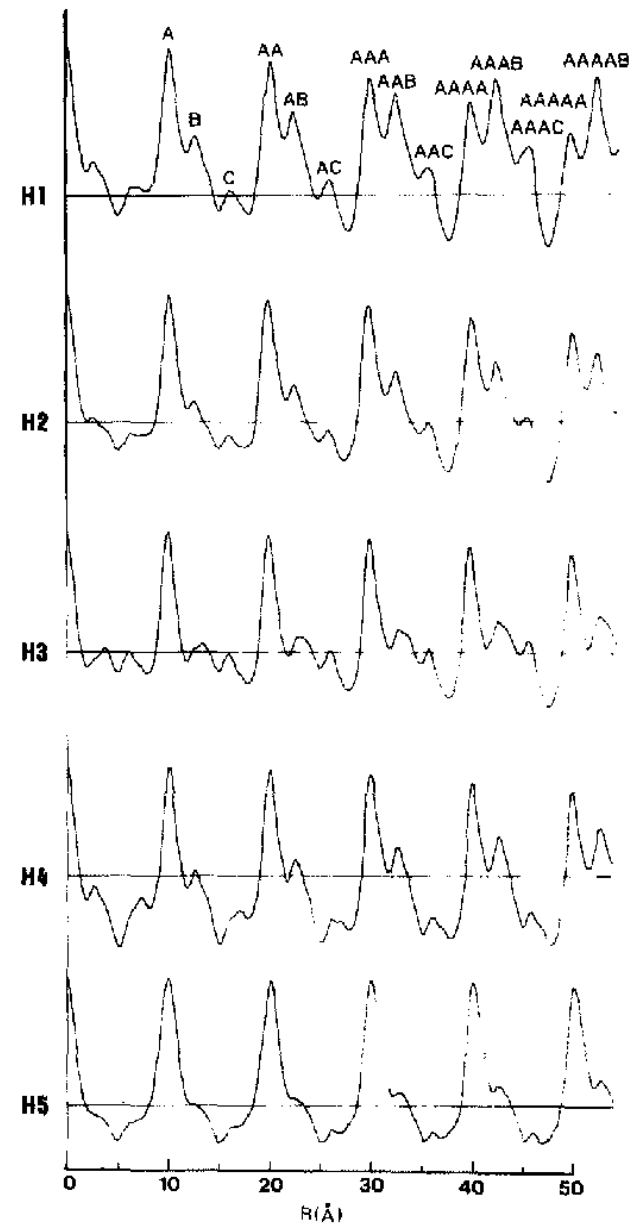

Fig. 3. Fourier transform of basal reflections for $\mathrm{Na}$-saturated hydromuscovites at $50 \% \mathrm{R}$. H. splits into two reflections (13.4 and 9.4 $\AA$ ), and that of other four specimens shifts slightly to higher angle. Fig. 4 shows Fourier transforms of basal reflections for the specimens. These transforms suggest that the specimens contain about 12.5 (B) and 18 (D) $\AA$ component layers, which are assigned to expandable layers with one-layer glycerol complexes and those with two-layer glycerol complexes. The restricted expansion with glycerol for $12.5 \AA$ component layers of $\mathrm{Mg}$-saturated specimens agrees with the swelling behavior of vermiculite (Walker, 1957, 1958).

\section{Diseussion and Summary}

Hydration states and nature of the interstratifications of the hydromuscovites were examined by means of Fourier transform method under the conditions of $80 \%$ and $50 \%$ R.H. for $\mathrm{Ca}$ - and $\mathrm{Na}$-saturated specimens and glycerol solvated complexes of $\mathrm{Mg}$-saturated specimens.

Under the condition of $80 \%$ R.H., Ca-saturated specimens $\mathrm{H} 1, \mathrm{H} 2$ and $\mathrm{H} 3$ show interstratifications of three component layers, which are mica layer, expandable layer of onelayer hydration and that of two-layer hydra. tion. The existing ratios of expandable layer of two-layer hydration to that of one-layer decrease with increasing the proportions of 
Table 6. Spacings ( $\AA$ ) and intensities of basal reflections for glycerol solvated complexes of $\mathrm{Mg}$-saturated hydromuscovites

\begin{tabular}{|c|c|c|c|c|c|c|c|c|c|}
\hline \multicolumn{2}{|c|}{$\mathrm{H} 1$} & \multicolumn{2}{|c|}{$\mathrm{H} 2$} & \multicolumn{2}{|c|}{$\mathrm{H3}$} & \multicolumn{2}{|c|}{$\mathrm{H} 4$} & \multicolumn{2}{|c|}{ H5 } \\
\hline$d(\AA)$ & $I$ & $d(\AA)$ & I & $d(\AA)$ & $I$ & $d\left(\begin{array}{l}n \\
2\end{array}\right)$ & I & $\mathrm{d}(\stackrel{\circ}{A})$ & I \\
\hline 13.4 & 245 & & & & & & & & \\
\hline 9.9 & 1000 & 9.9 & 1000 & 10.0 & 1000 & 10.1 & 1000 & 10.1 & 1000 \\
\hline 4.88 & 194 & 4.96 & 327 & 4.96 & 342 & 4.98 & 175 & 5.01 & 339 \\
\hline 3.352 & 455 & 3.357 & 478 & 3.334 & 489 & 3.336 & 544 & 3.345 & 479 \\
\hline 2.525 & 28 & 2.518 & 28 & 2.512 & 25 & 2.584 & 44 & 2.511 & 29 \\
\hline 1.998 & 109 & 2.001 & 128 & 1.998 & 132 & 1.996 & 182 & 2.002 & 150 \\
\hline 1.646 & 4 & 1.654 & 4 & 1.661 & 2 & 1.667 & 4 & 1,656 & 3 \\
\hline 1.422 & 5 & 1.429 & 6 & 1.425 & 5 & 1.428 & 10 & 1.429 & 5 \\
\hline 1.250 & 5 & 1.254 & 7 & 1.245 & 5 & 1.248 & 16 & 1.251 & 8 \\
\hline
\end{tabular}

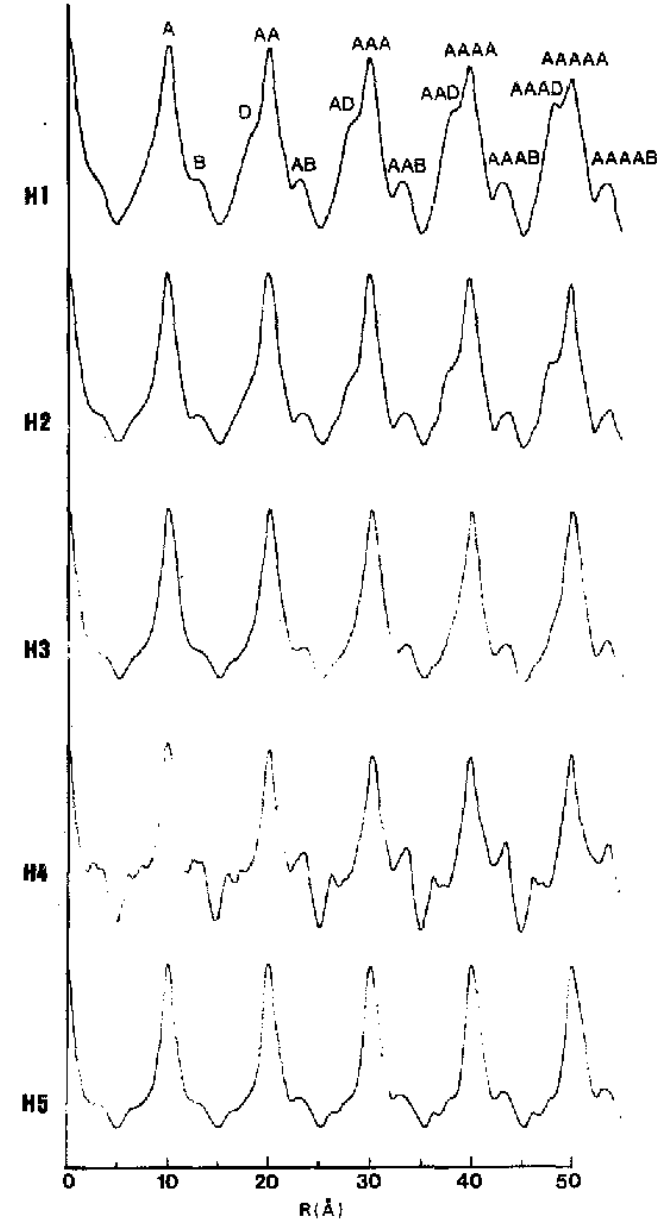

Fig. 4. Fourier transform of basal reflections for glycerol solvated complexes of $\mathrm{Mg}$-saturated hydromuscovites. mica layer components. Specimens $\mathrm{H} 4$ and $\mathrm{H} 5$, which have larger proportions of mica layer than those of the above three specimens, show interstratifications of two component layers, which are mica layer and expandable layer of one--layer hydration. Glaeser and Méring (1968), Suquet et al. (1975) and Watanabe and Sato (1988) reported the basal spacings of $\mathrm{Ca}$-saturated smectites under the conditions of various relative humidities, and pointed out that $\mathrm{Ca}$-saturated smectites retain two layers of water molecules in interlayer positions in the range of relative humidities between about $30 \%$ and $90 \%$ R.H. Similar expansion characteristics of expandable layer of regularly interstratified mica/smectites have been reported by Matsuda (1984). The hydration states in the interlayers of hydromuscovites examined in this study show inhomogeneity of one- and two-layer hydration states, and the ratios of two-layer hydration to one-layer decrease with increasing the proportions of mica layer components. These hydration states may be the result of high layer charge and inhomogeneous charge density distribution in expandable layers.

Under the condition of $50 \%$ R.H., the Casaturated specimens show a little decrease in two-layer hydration, and $\mathrm{Na}$-saturated speci- 
mens show further decrease in two-layer hydration and increase in one-layer hydration. Although, the $\mathrm{x}$-ray diffraction data demonstrated shrinking behaviors of expandable layers, the expandable layers of two-layer hydration did not show continuous contraction. The changes of hydration states of expandable layers indicate that the values of layer charge are higher than those of regularly interstratified mica/smectites and usual smectites, and the values increase with increasing the proportions of mica layer components. The Fourier transforms of glycerol solvated complexes of $\mathrm{Mg}$ saturated specimens also indicate the presence of high charge expandable layers which have vermiculite-like expansion properties.

The differences of hydration behaviors of hydromuscovites from those of regularly interstratified mica/smectites and usual smectites are considered to be due to high layer charge in expandable layers of the hydromuscovites.

Acknowledgements: The authors thank Ms. E.J.D. Mamaril, Faculty of Science, Kagoshima University, for her critical reading of the manuscript.

\section{References}

Bailey, S.W. (1980), Summary of recommendations of AIPEA Nomenclature Committee. Clay Minerals, 15, 85-93.

Cole, W.F, and Lancucki, C.J.C. (1966), Tabular data of layer structure factors for clay minerals. Acta Crystal., 21, 836-838.

Glaeser, R. and Méring, J. (1968), Homogeneous hydration domains of the smectites. C.r. febd. Seanc. Acad. Sci., Paris, 267, 436-466.

Grim, R.E., Bray, R.H. and Bradley, W.F. (1937),
The mica in argillaceous sediments. Amer, Mineral., 7, 813-829.

Hower, J. and Mowatt, M. (1966), The mineralogy of illites and mixed layer illite/montmorillonites. Amer. Mineral., 51, 825-854.

Kawano, M. (1988), Interstratified mica/smectite in the Ten-ei district, Fukushima Prefecture. J. Min. Petr. Econ. Geol, , 83, 241-248 (in Japanese with English abstract).

Kawano, M. and Tomita, K. (1988), Ammoniumbearing dioctahedral $2 \mathrm{M}_{1}$ mica from Aira district, Kagoshima Prefecture. Clay Sci., 7, $161-169$.

Kodama, H. (1957), Sericite from Ozawa-mura, Gumma Prefecture. Mineral. J., 2, 151-161.

Kodama, H. (1962), Interpretation of X ray pow. der patterns of some hydromuscovites from Japan, with reference to their alkali contents. Clay Sci., 1, 89-99.

MacEwan, D.M.C. (1956), Fourier transform methods for studying scattering from lamellar systems, I. A direct method for analysing interstratified mixtures. Kolloid $Z$., 149, 96108.

Matsuda, T. (1984), Mineralogical study on regularly interstratified dioctahedral micasmectites. Clay Sci., 6, 117-148.

Shimoda, S. (1970), A hydromuscovite from the Shakanai mine, Akita Prefecture, Japan. Clay and Clay Minerals, 18, 269-274.

Shirozu, H. and Higashi, S. (1972), X-ray examination of sericite minerals associated with the Kuroko deposits. Clay Sci., 4, 137-142.

Suquet, H., De La Calle, C. and Pezerat, H. (1975), Swelling and structural organization of saponite. Clay and Clay Minerals, 23, 1-9.

Walker, G.F. (1957), On the differentiation of vermiculites and smectites in clays. Clay Miner. Bull. 3, 154-163.

Walker, G.F. (1958), Reactions of expanding lattice minerals with glycerol and ethylene glycol. Clay Miner. Bull., 3, 302-313.

Watanabe, T. and Sato, T. (1988), Expansion characteristics of montmorillonite and saponite under various relative humidity conditions. Clay Sci., 7, 129-138. 


\title{
ハイドロマスコバイトの層間水和状態
}

\author{
河野 元治, 富田 克利
}

ハイト゚ロマスコバイトの膨潤層層間陽イオンを様々の陽イオンで交换後, 相対湿度 $80 \%, 50 \%$ 枕よびグ リセロール処理挠の水和状態をフーリエ恋換に上って険討した。

Ca 飽和試料は相㳔湿度 $80 \%$ の条件で膨潤層層間に一層と二層の水分子層が存在し, 雲母層の增加に伴

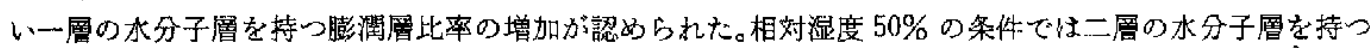
膨潤層が隇少し，一層の水分子層を持つ膨潤層が増加した。 $\mathrm{Mg}$ 飽和後のグッセロー八处理では $12.5 \AA$ の面 間隔を持つ一層のグリセロール分子复合体が認められた。

これらの層間水和状態はスメクタイトおよび規則型雲母/スメクタイト混合層鉱物とは異なり,膨潤層の 高い層電荷に起因するものと思われる。 